OECD Economics Department Working Papers No. 92

\title{
Unemployment Persistence and Insider-Outsider Forces in Wage Determination
} Bertil Holmlund 


\section{OECD \\ DEPARTMENT \\ OF ECONOMICS AND STATISTICS}

\section{WORKING PAPERS}

No. 92: UNEMPLOYMENT PERSISTENCE AND INSIDER-OUTSIDER FORCES IN WAGE DETERMINATION

by

Bertil Holmlund

February 1991

\section{OCDDE}

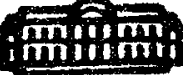

OEBCD 



\title{
ECONOMICS AND STATISTICS DEPARTMENT \\ WORRING PAPERS
}

\begin{abstract}
This series of Working Papers is designed to make available, to a wider readership, selected studies which the Department has prepared for use within OECD. Authorship is generally collective, but main individual authors are named.

Comment on the Papers is invited, and may be sent to OECD, Department of Economics and Statistics, 2 rue André Pascal, 75775 Paris Cedex 16, France. Additional copies of the Papers on a limited basis can be forwarded on request.
\end{abstract}

\section{ORGANISATION FOR ECONOMIC CO-OPERATION AND DEVELOPMENT}

Copyright OECD, 1991 
The rise in European unemployment has inspired much new research on the causes and mechanisms of unemployment, analogous to the interest devoted to unemployment in the 1930s. The new research has to a large extent focused on wage-setting behaviour, as is revealed by the rapid growth of theoretical and empirical work on models of wage bargaining, insider-outsider relationships. and efficiency wages. A common theme in this new work is a desire to provide satisfactory microeconomic foundations for the existence and persistence of involuntary unemployment.

This paper offers a survey of recent research on unemployment persistence and insider-outsider forces in wage determination. It begins in Section II with an overview of major themes in the theoretical work on unemployment. Section III reviews results from a number of recent empirical studies inspired by these new theories. Section IV concludes with a discussion of directions for future research.

La montée du chômage en Europe a suscité de nombreuses nouvelles pistes de recherche sur les causes et les mécanismes du chômage, de manière analogue à l'intérêt porté sur le chômage des années 30 . Les analyses se sont dans une large mesure centrées sur la formation des salaires, comme en témoigne le développement rapide des travaux théoriques et appliqués sur le modèle de négociation, les relations "insider-outsider" et le salaire d'efficience. Un thème commun à ces nouveaux travaux est le désir d'apporter des fondations macro-économiques solides à l'existence et la persistence du chômage involontaire.

\footnotetext{
Le papier présente un panorama des recherches récentes sur la persistence du chômage et les influences "insider-outsider" dans la détermination des salaires. Section II donne un aperçu des principaux thèmes de la recherche théorique sur le chômage. Section III fournit une revue des résultats d'études empiriques récentes inspirées par ces théories nouvelles. Section IV conclut avec une discussion des directions possibles pour la recherche future.
} 
No. 92: UNEMPLOYMENT PERSISTENCE AND INSIDER-OUTSIDER

FORCES IN WAGE DETERMINATION

by

Bertil Holmlund

Eebruary 1991

The author is Professor of Economics at Uppsala University. He prepared this paper as Consultant to the Economics and Statistics Department. He is grateful to Per-Anders Edin. Steve Englander. David Grubb.. John Martin, Barry McCormick and Peter Robinson for helpful comment's. The views expressed are not necessarily those of the OECD or of the governments of its Member countries. 


\section{TABLE OF CONTENTS}

I. Introduction 1

II. Theoretical Issues * 2

1. Introduction 2

2. Models of equilibrium unemployment 3

a) Search and matching models. 3

b) Models of wage bargaining . 3

c) Efficiency wage models

3. Insider power 1

4. Outsider ineffectiveness 7

5. Hiring and firing costs 8

III. Empirical Evidence 9

1. Introduction 9

2. Unemployment persistence 9

a) Explaining cross-country variations $\quad 10$

b) Job security provisions 13

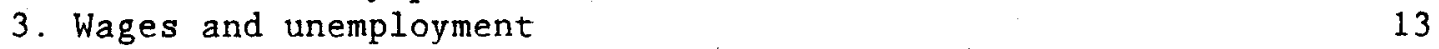

a) Non-linearities and long-term unemployment 14

b) Membership effects 18

c) Moving natural rates 18

4. Wages and firm performance 19

5. Duration dependence in unemployment 20

Long-term unemployment and search effort in Britain 21

6. Conclusions 22

IV. Directions for Euture Research 23

1. Wage determination 24

2. Individual behaviour during unemployment 24

3. Employers' recruitment behaviour 25

$\begin{array}{ll}\text { References } & 26\end{array}$ 


\section{INTRODUCTION}

The rise in European unemployment has inspired much new research on the causes and mechanisms of unemployment, analogous to the interest devoted to unemployment in the $1930 \mathrm{~s}$. The new research has to a large extent focused on wage setting behaviour, as is revealed by the rapid growth of theoretical and empirical work on models of wage bargaining. insider-outsider relationships. and efficiency wages. A common theme in this new work is a desire to provide satisfactory microeconomic foundations for the existence and persistence of involuntary unemployment.

The research on unemployment is related to, although distinct from, the remarkable revival of research on inter-industry wage differentials that has occurred over the past few years. (See for example OECD 1986, Katz and Summers 1989. Krueger and Summers 1988, and Edin and Zetterberg 1989.) This research has addressed old issues using new theoretical perspectives, new data sets. and refined econometric methods. There is a growing amount of evidence suggesting that the inter-industry wage structure cannot be fully explained by differences across industries in workers' skills, or differences in working conditions that may require compensating wage differentials. Evidence from the United States indicates that industry affiliation has large relative wage effects, even after controlling for differences in workers' human capital attributes and demographic background. The new findings offer striking confirmations of old non competitive themes in studies of wage determination. Empirical work from the late 1940 s and the early 1950 s typically found that industry performance had significant effects on the wage structure, results that were difficult to reconcile with standard competitive labour market models (Dunlop 1948, Slichter $1950)$.

Non-competitive wage differences may be viewed as a kind of rent sharing. and rent sharing is most naturally thought of in a bargaining context. When there is bargaining over wages at the firm or industry. level, the firm's or sector's performance is likely to be crucial for the wage outcome. Suppose, to take an extreme case, that wages are determined by a group of employed insiders facing small risks of loosing their jobs. Selfish insiders may well ain at wage gains for themselves - rather than employment for unemployed outsiders - - when the firm experiences a product demand improvement. Insider wage setting may then also cause hysteresis (history dependence) in employment and unemployment (see Franz 1990 for definition and discussion of the hysteresis concept). Adverse shocks to labour demand reduce the number of insiders. and wages set in the next period will reflect the interests of this smaller group of workers. Temporary shocks to labour demand may have permanent effects on employment to the extent that powerful insiders ignore the interests of unemployed outsiders.

This paper offers a survey of recent research on unemployment persistence and insider-outsider forces in wage determination. (See Nickell. 1990 for a survey of modern research on unemployment in general.) We begin in Section II with an overview of major themes in the theoretical work on unemployment. Section III reviews results from a number of recent empirical studies of unemployment persistence and insider power in wage determination. Section IV concludes with a discussion of directions for future research. 


\section{THEORETICAL ISSUES}

\section{Introduction}

The famous article by A.W. Phillips (1958) on wage inflation and unemployment in the United Kingdom initiated an enormous amount of research on wage determination. This research was for a decade or so primarily empirical. aiming at quantification of the relationship between unemployment and wage increases and the associated trade-off between unemployment and price inflation. The existence of such a relationship was taken for granted, with the implication that any government with suitable fiscal and monetary policies could choose its desired mix of inflation and unemployment.

The idea of a stable long-run inflation-unemployment trade-off was forcefully criticișed by Milton Friedman and Edmund Phelps in the late 1960s. a period during which the "naive" Phillips curve also became less accurate as a description of empirical regularities. Friedman and Phelps suggested that unemployment and inflation were independent in the long run. implying a vertical long-run Phillips curve.

The insights provided by Friedman and Phelps were quickly incorporated into mainstream textbooks and econometric models if the form of the expectations-augmented Phillips curve. This model of wage or price inflation stressed the importance of inflationary expectations, and took as a maintained hypothesis the idea that economic agents lack money illusion. It should therefore not be possible to exploit a long-run trade-off between unemployment and inflation.

The expectations-augmented Phillips curve can be used to compute the natural rate of unemployment, as can be illustrated by means of a simple example. Suppose that prices are determined as a mark-up on wages and that wage inflation is driven by excess demand in the labour market as well as by expected price inflation. Let the unemployment rate serve as a proxy for excess labour demand, and let the log of the price level be denoted by $p$ and price inflation by $\Delta \mathrm{p}$. The assumptions imply that price inflation is determined by unemployment $(u)$ and expected inflation $\left(\Delta p^{e}\right)$, i.e.,

$$
\Delta \mathrm{p}=\alpha+B u+\gamma \Delta \mathrm{p}^{\mathrm{e}}
$$

The natural rate hypothesis implies $\gamma=1$. An equilibrium without price surprises involves $\Delta \mathrm{p}^{\mathrm{e}}=\Delta \mathrm{p}$, and the natural rate can be solved out from-[1] as $u^{*}=-\alpha / B$.

An offspring of the natural rate hypothesis is the so-called NAIRU hypothesis, where NAIRU stands for the non-accelerating inflation rate of unemployment. Suppose that expectations about inflation are formed adaptively. for example as $\Delta \mathrm{p}^{\mathrm{e}}=\Delta \mathrm{p}_{-1}$, where $\Delta \mathrm{p}_{-1}$ is last period's inflation. Substituting into [1] and assuming $\gamma=1$ yields:

$$
\Delta \mathrm{p}-\Delta \mathrm{p}_{-1}=\alpha+B \mathrm{u} \text {. }
$$

We have now arrived at a relationship between the rate of change in inflation and unemployment. The NAIRU is the unemployment rate that is consistent with 
unchanging inflation, i.e. NAIRU $=-\alpha / \beta$. NAIRU is independent of the inflation rate. however: the long-run Phillips curve is vertical.

\section{Models of equilibrium unemployment}

Although the expectations-augmented Phillips curve may be a convenient econometric device to estimate the equilibrium unemployment rate, it is not very informative about the underlying forces that determine the equilibrium. The past two decades have seen a considerable amount of theoretical work attempting to fill this gap. The theoretical approaches have been diverse, and we briefly discuss three major research directions, namely i) search and matching models: ii) wage bargaining models; and iii) efficiency wage models.

\section{a) Search and matching models}

Search and matching models portray labour markets with trading frictions (see Pissarides, 1990). These frictions are associated with imperfect information and costly search, on both sides of the market; workers have to expend resources in order to locate vacancies and firms must engage in search for suitable employees. These models deliver equilibrium with unemployment. and the resulting equilibrium unemployment rate depends, inter alia, on the matching technology and unemployment benefits.

The equilibrium unemployment rate is in general not efficient in these models. There are various trading externalities due to the fact that individual searchers - - workers as well as firms -. do not take into account how their decisions will affect other searchers. The equilibrium unemployment rate may be too high or too low from the point of view of social efficiency. and there is in general room for policy interventions to improve on the laissez-faire outcome.

Standard matching models may produce unemployment persistence, in the sense that temporary shocks have prolonged effects on unemployment. Unemployment will however return to normal as time goes by; temporary shocks have no permanent effects on unemployment. There are circumstances, however, under which multiple equilibria occur in these kinds of models (see Mortensen, 1989). Multiple (un)employment equilibria are possible if there are i) increasing returns in production, or ii) increasing returns in the matching technology in the sense that a doubling of the number of unemployed and vacancies doubles the flow of new hires. Temporary shocks to the economy may then have permanent effects on the unemployment rate: the economy may be pushed from a high-employment equilibrium to a low-employment equilibrium. The empirical relevance of this class of models is very much an open question: empirical work on aggregate matching functions does not support the idea that the matching technology exhibits increasing returns to scale.

\section{b) Models of wage bargaining}

Models of unions and wage bargaining have by now appeared in many guises. (See Oswald. 1985; Pencavel, 1985; and Holmlund, 1989 for recent surveys.) A standard model portrays a union with preferences over employment and real wages. There are negotiations over the wage, and possibly over employment as well: in the latter case we have the so-called efficient bargain model. where the assumption is that all possible gains from trade between the 
union and the firm are exploited. Bargaining over employment is rarely seen in practice (see Clark and Oswald, 1989), and most models of union-firm bargaining have assumed that employment is left to the firm's discretion after the wage has been agreed upon; these models are often referred to as "right-to-manage" models. The union recognises that a higher wage involves lower employment as the firm moves up on its labour demand curve. The wage outcome of this bargain depends, inter alia, on the power of the union; an extreme case is one where a monopoly union is able to completely enforce its wage demands on the firm.

Wage bargaining models yield several implications concerning the determinants of equilibrium unemployment. Unemployment iș higher the higher is real unemployment benefits and the degree of union power; unemployment is lower the higher is the wage elasticity of labour demand. Unemployment is determined by "real" forces only; there is no role for traditional aggregate demand policy in shaping the equilibrium unemployment rate.

Deviations between actual and equilibrium unemployment occur if there are inflationary surprises. A convenient stylised model, where the equilibrium unemployment rate is the level of unemployment which "brings peace in the battle of the mark-ups", can be outlined as follows (see Layard and Bean. 1989). First, there is a price setting relationship:

$$
p-w^{e}=a_{0}-a_{1} u,
$$

where $p$ is the $\log$ of the output price, $w^{e}$ is the $\log$ of the expected wage and $u$ is the unemployment rate. Firms set prices on the basis of expected marginal costs, and the price mark-up on wages may depend on the level of activity.

Wage-setters set wages on the basis of expected prices, with the mark-up inversely dependent on the unemployment rate, i.e.

$$
\text { w - } \mathrm{p}^{\mathrm{e}}=\mathrm{b}_{0}-\mathrm{b}_{1} \mathrm{u} \text {. }
$$

which reflects the idea that unemployment moderates real wage claims. The coefficients of this real wage equation incorporate institutional features of the labour market, such as the benefit system and the wage bargaining structure.

$$
\begin{aligned}
& \text { Finally, there is an equation for aggregate demand. } \\
& u=c_{0}-c_{1}(m-p)
\end{aligned}
$$

where $\mathrm{m}$ is the $\log$ of the money stock.

Equations [3] to [5] determine unemployment as:

$$
u=\frac{a_{0}+b_{0}-\left(p-p^{e}\right)-\left(w-w^{e}\right)}{a_{1}+b_{1}}
$$

Unemployment is thus negatively related to price and wage surprises. Suppose that there is an unanticipated increase in nominal aggregate demand. Wage 
setters set nominal wages based on expected prices; if prices turn out to be higher than expected. real wages will be lower than expected and this allnws a reduction in unemployment. To the extent that price and wage surprises are associated, with changes in inflation, as will be the case if inflationary expectations are formed adaptively, there will be an inverse relationship between unemployment and changes in inflation (as in the simple expectations-augmented Phillips curve with adaptive expectations).

The equilibrium unemployment rate is the unemployment rate that obtains when there are no price or wage surprises, i.e.

$$
u^{*}=\frac{a_{0}+b_{0}}{a_{1}+b_{1}}
$$

This unemployment rate is determined by real forces only and is independent of nominal aggregate demand.

\section{c) Efficiency wage models}

Efficiency wage models are based on the idea that the firm may benefit from paying a wage above the market-clearing level (see Akerlof and Yellen. 1987). The firm may, for example, be able to reduce shirking among its employees by paying a slightly higher wage than its competitors. A higher wage means that a worker contemplating shirking has more to loose by actually doing so: if being caught as shirker and fired, his income loss will be greater the higher is his wage. The firm may also benefit from paying a high wage through a reduction in turnover, or through a higher quality of the pool of job applicants.

However, all firms cannot simultaneously raise their relative wages in order to reduce shirking or turnover. The aggregate outcome of the firms' wage competition may entail a wage level incompatible with full employment. Unemployment is involuntary in this case, in the sense that an unemployed worker cannot attract a job by offering to work at a slightly lower wage than workers currently employed; each firm has chosen a profit-maximising efficiency wage and does not find it profitable to deviate from it.

Unemployment arises because of a monitoring problem. The firm cannot directly observe and control effort and must resort to using its wage policy as an incentive device. The resulting level of unemployment will be determined by the properties of the function that relates effort (or shirking or turnover) to (relative) wages and unemployment. In most efficiency wage models there will also be a relationship between unemployment and the level of unemployment benefits: shirking or quits will be less costly the higher is the benefit level.

Efficiency wage models have in general been developed without much attention being paid to dynamics. Plausible and straightforward extensions may however produce unemployment persistence with respect to temporary shocks. Suppose, for example, that work effort responds to the actual wage relative to what is perceived as a "fair" wage, the latter being established through historical experience. It is then easy to generate prolonged unemployment as a response to temporary shocks. 
This concludes our brief discussion of models of equilibrium unemployment. Although based on different institutional and behavioural assumptions, the models have important features in common. They are a11 "real" models in which there is no role for monetary shocks to permanently affect unemployment (except for the case with multiple equilibria). The models are also, at least in their original and "pure" form, silent about dynamics and hence they do not explain persistence in unemployment. The models can however be generalised to deliver predictions about sluggish real wage behaviour. a topic to which we now turn.

\section{Insider power}

The natural rate framework could only with difficulty account for the high European unemployment during the 1980s. A common finding in empirical work based on expectations-augmented Phillips curves was that the estimated natural rate tracked the actual unemployment rather closely. This finding inspired some analysts to search for structural explanations of the increase in the natural rate (such as changes in the benefit system, union power. employment security legislation. etc.). Another line of research. the so-called "insider-outsider" models, associated with work by Blanchard and Summers (1986) and Lindbeck and Snower (1988), adopted a more radical approach and abandoned the natural rate framework.

The basic idea in insider-outsider models of unemployment is that unions primarily act in the interest of a group of insiders, which consists of workers currently employed (or a subset of those, such as those who are insulated from lay-off risks via long tenure). When product market conditions improve. the insiders are more likely to secure wage gains for themselves rather than allow employment increases to the benefit of unemployed outsiders.

The insider-outsider models typically consider union wage setting. or wage bargaining, under uncertainty about labour demand. In the Blanchard-Summers model, the wage is set so as to ensure the continued employment of insiders. If adverse shocks to labour demand reduce the number of insiders, there will be no automatic return to the original employment level as labour demand conditions improve; the new smaller group of insiders can set a higher wage in order to secure their continued employment. One clear implication of this model is that employment follows a random walk, with no tendency to return to a "natural" level.

The Blanchard-Summers model is extreme in that it allows no role for outside labour market pressure to affect the decisions of insiders. Less extreme, and more realistic, models of wage setting with insider power have been developed by, for example. Nickell and Wadhwani (1990). In their model there is uncertainty about labour demand and the union cares about the employed worker's expected utility. The latter depends on the worker's layoff probability, which is higher - for any given realisation of labour demand the higher the initial employment level is. The worker's expected utility also depends on his/her options if laid off: the higher the unemployment rate. the more difficult it is to locate a new job.

The wage agreed upon in the negotiations will, in general, depend both on the size of the insider work force, the firm's productivity and product demand conditions, and prevailing outside labour market conditions, such as the 
unemployment rate, the average wage outside the firm and the level of unemployment benefits. Following the Nickell-Wadhwani model, the firm-level wage equation can be written as:

$$
w=\alpha_{0}+\alpha_{1}\left(p+q-\delta_{1} n_{-1}\right)+\left(1-\alpha_{1}\right)\left(\bar{w}-\delta_{2} u+\delta_{3} b\right)
$$

or as:

$$
w-\bar{w}=\alpha_{0}+\alpha_{1}(p+q-\bar{w})+\gamma_{1} n-1+\gamma_{2} u+\gamma_{3} b
$$

where (all variables in logs) $p$ is the output price, $q$ is a productivity factor, $n_{-1}$, is the initial employment level, $\bar{w}$ is the average wage outside the firm, $u$ is the unemployment rate and $b$ is the benefit level. The $\delta_{i}$-parameters can be recovered by using the estimates of $\alpha_{1}$ and $\gamma_{i}$ from equation [8']. The assumption is that the size of the insider group is equal or proportional to the initial employment level. The model predicts an inverse relationship between the wage and initial employment. This is a key hypothesis delivered by insider-outsider models of wage setting.

The implications for aggregate wage equations are obtained by setting $w=\dot{w}$ in [8], assuming that the sectors are identical, and solving for the real wage to obtain an aggregate real wage equation. The negative relationship between wages and lagged employment in [8] translates at the aggregate level into a positive relationship between wages and lagged unemployment. The wage depressing effect of higher unemployment is thus bigger in the short run than in the long run.

Hysteresis effects in wage equations need not derive solely from insider forces, however. An equally plausible hypothesis focuses on the behaviour of the unemployed, in particular their search effort during prolonged spells of unemployment.

\section{Qutsider ineffectiveness}

This hypothesis, associated primarily with Layard and Nickell, stresses the adverse effects of long-term unemployment. Several mechanisms may be at work. An unemployed worker may, for example, reduce his search effort as the length of the spell of unemployment increases, perhaps due to deteriorating morale or other psychological effects of prolonged unemployment. The worker may also become less attractive as a job applicant viewed from the employer's point of view as unemployment duration increases; this may be due to depreciation of human capital or to the employer's belief that the long-term unemployed are inherently less productive workers. According to this hypothesis, the exit rate from unemployment to employment is likely to decrease with prolonged unemployment.

If long-term unemployment reduces the effectiveness of job search, this also means that long-term unemployment should involve less downward pressure on wages than short-term unemployment. The higher the fraction of long-term unemployed, the lower the number of effective job searchers for any given level of total unemployment. An adverse shock to labour demand may then generate 
hysteresis since the proportion of long-term unemployed depends on current and past levels of unemployment. The exact form of this link between long-term unemployment and current and past unemployment is entirely an empirical matter, but it is clear that the mechanism delivers the possibility of history-dependence in real wages and unemployment.

The outsider ineffectiveness hypothesis is plausible but has not been rigorously derived from a job search model. A partial exception is a paper by Blanchard and Diamond (1990), which develops a matching model based on a specific hiring rule, called ranking. The idea is that firms select job applicants with the shortest spell of unemployment. Wage bargaining takes place after the worker is hired, and the worker's threat point in the bargain is given by the value of being a worker with zero unemployment duration. The model yields several strong predictions. The escape rate from unemployment is decreasing with elapsed duration, so there is so-called "negative duration dependence". The model also implies that long-term unemployment has little effect on wages, the reason being that the worker's threat point in the wage bargain is the value of being unemployed with zero duration. These results are derived without relying on any adverse effects from unemployment per se; the key assumption that drives the results is that firms base their hirings on the applicants' unemployment duration.

Hiring and firing costs

A popular explanation of Europe's poor employment record since the mid-1970s emphasises labour adjustment costs. The idea is that employment security provisions, introduced either by legislation or under pressure from strong unions, have made it more costly to firms to reduce their work force in the face of a downturn in product demand. These higher layoff costs may in turn make firms more reluctant to hire new workers when product demand is improving. In general, higher firing costs are assumed to reduce firms' average employment by making labour a more costly factor of production.

The idea that employment security provisions are likely to make employment less sensitive to product demand. fluctuations is almost self-evident; higher firing costs involve incentives to smooth employment relative to movements in product demand. This should translate into more sluggish behaviour of unemployment: put differently, unemployment is likely to exhibit some persistence.

Whether or not job security provisions reduce employment on average over the cycle is another and much more complicated issue. Bertola (1990) has offered interesting new theoretical results on this matter by using a dynamic stochastic model of a firm with forward-looking behaviour. He derives the expected result that firing costs make firms more reluctant to hire in good times because they will fire less in bad times. But he also shows that firing costs need not lead to lower employment on average, although such costs reduce the firm's profits.

These results regarding employment behaviour are obtained under the assumption of an exogenously given path of wages. Bertola also considers how employment protection influences wage setting in an insider-outsider type model. The analysis offers little support for the idea that employment 
security provisions per se tend to bias wage determination towards higher wages and lower employment.

\section{EMPIRICAL EVIDENCE}

\section{Introduction}

Empirical evidence on the persistence of unemployment can be found in many quarters, and a variety of theoretical frameworks and data sets have been used in recent empirical work. One research direction, exemplified by Barro (1988), investigates the properties of time series on unemployment in order to estimate the degree of persistence and to compare persistence across different countries and time periods. This approach may also involve attempts to explain inter-country variations in persistence by variables that capture important institutional features of labour markets in different countries.

Insider-outsider models focus on wage-setting behaviour, and the relative importance of insider and outsider variables is crucial for understanding how the economy responds to shocks in such models. The extreme versions of insider-outsider models predict that the level of unemployment exerts no downward pressure on wages at all, a prediction that typically is refuted in empirical studies. Most insider-outsider models imply an inverse relationship between wages and the size of the incumbent work force, and this prediction has been tested in several studies (with mixed results, as we shall see). Models that emphasise outsider ineffectiveness suggest that long-term unemployment should have little or no wage-moderating effects, and some studies have tested this hypothesis using both macro and micro data.

Standard competitive labour market models allow no long-run relationship at the micro level between wages and the firm's performance; wages are determined by workers' characteristics and by non-pecuniary job attributes that may result in compensating wage differentials. Insider-outsider models, by contrast, emphasise rent sharing; workers are able to share rents with employers, and a positive relationship between wages and firm performance can thus prevail. Several recent studies have addressed issues concerning rent sharing using data sets for a number of different countries.

Models emphasising outsider-ineffectiveness rely heavily on the presumption that long-term unemployment has adverse individual effects. It is, for example, frequently assumed that the individual job seeker's probability of leaving unemployment falls as the elapsed duration of unemployment increases. Many microeconometric studies have examined the importance of such (negative) duration dependence- the empirical support for the hypothesis turns out to be less than overwhelming, however.

\section{Unemployment persistence}

The procedure followed by Barro (1988) and others involves estimating unemployment equations of the form:

$$
u_{t}=\alpha_{0}+\alpha_{1} u_{t-1}+\epsilon_{t}
$$


where $\mathrm{u}$ is the unemployment rate (possibly in logs). The parameter $\alpha_{1}$ captures the degree of persistence in unemployment; $\alpha_{1}=0$ corresponds to no persistence at all, whereas $\alpha_{1}=1$ represents the case where unemployment follows a random walk. Persistence in this sense captures the speed at which unemployment responds to shocks and says nothing about the level of unemployment. Barro's results from estimating [9] are reproduced in Table 1.

The results indicate substantial persistence during the post-World War II period. Fifteen of the 18 point estimates of $\alpha_{1}$ exceed 0.8 , but a joint hypothesis that all coefficients are equal to unity is rejected. The countries with least persistence are Sweden, Israel, the United States and Switzerland; the estimated autoregressive (AR1) coefficients for these countries are, in turn, $0.52,0.65,0.74$ and 0.75 .

Barro's results also show much less unemployment persistence for periods before World. War II. For Germany and the United Kingdom, the estimated ARl-coefficients for the early part of the century are roughly half their post-World War II magnitude. It seems likely, however, that this increase in estimated persistence partly captures structural shifts in the level of unemployment.

Blanchard and Summers (1986) examined employment and unemployment processes in four countries - - Germany, the United Kingdom, France and the United States - - and they noted much stronger hysteresis for the three. European countries compared to the United States: "... the process generating unemployment appears non-stationary in all three European countries, whether or not a time trend is included in the regressions.". (Blanchard and Summers, p. 58).

\section{a) Explaining cross-country variations}

Barro's study also attempted to explain differences across countries in unemployment persistence by relating the estimated AR1-coefficients to the degree of unionisation and the degree of centralisation in wage bargaining structures. An estimated equation based on data including the pre-World War II period takes the following form (standard errors are in parentheses):

$$
\begin{aligned}
& \mathrm{AR} 1=1.05 \cdot \mathrm{CORP}+0.65 \cdot \mathrm{LIB} \\
& (0.14) \quad(0.07) \\
& -0.36 \cdot \text { CORP UNION }+0.86 \cdot \text { LIB } \text { UNION } \\
& (0.27) \quad(0.25)
\end{aligned}
$$

CORP is dummy for economies classified as "corporatist" due to a predominantly economy-wide wage bargaining structure, LIB $=1$-CORP stands for "liberal" economies, and UNION measures union density. All countries before World War II were classified as liberal, and UNION is measured as average for the sample period. The regression results support the idea that unions contribute to higher persistence among economies that lack corporatist institutions, whereas unions do not seem to matter for persistence in the corporatist economies. One interpretation of this result could be that centralisation in wage bargaining is conducive to internalisation of some of the adverse effects of decentralised union power. 
Table 1

Unemployment persistence in different countries

Post-World War II

$\begin{array}{ll}\text { Australia } 1948-86 & 1.01 \\ \text { Austria 1948-86 } & 0.89 \\ \text { Belgium 1948-86 } & 0.88 \\ \text { Canada 1948-86 } & 0.88 \\ \text { Denmark 1948-86 } & 0.91 \\ \text { Finland 1959-86 } & 0.93 \\ \text { Erance 1950-86 } & 1.02 \\ \text { Germany 1950-86 } & 0.90 \\ \text { Ireland 1948-86 } & 0.98 \\ \text { Israel 1950-86 } & 0.65 \\ \text { Italy 1948-86 } & 0.93 \\ \text { Japan 1949-86 } & 0.94 \\ \text { Netherlands 1949-86 } & 0.91 \\ \text { New Zealand 1949-86 } & 1.03 \\ \text { Norway 1948-86 } & 0.95 \\ \text { Sweden 1948-86 } & 0.53 \\ \text { Switzerland 1948-86 } & 0.75 \\ \text { United Kingdom 1948-86 } & 1.08 \\ \text { United States 1948-86 } & 0.74\end{array}$

Pre-World War II

Australia $1920-38 \quad 0.69$

Belgium 1922-38 0.80

Canada $1920-38 \quad 0.72$

Denmark $1920-38 \quad 0.68$

Germany $1920-38 \quad 0.72$

Netherlands 1920-38 0.78

Norway 1920-38 0.64

Sweden $1920-38 \quad 0.39$

Switzerland 1925-38 0.82

United Kingdom $1920-38 \quad 0.59$

United States $1920-38 \quad 0.68$

Germany $1891-1913 \quad 0.46$

United Kingdom 1891-1913 0.62

United States 1891-1913 0.61

United Kingdom $1852-1890 \quad 0.19$

Note: The table shows AR1-coefficients estimated by Barro (1988). The dependent variable is the $\log$ of the unemployment rate. 
Barro also estimated the equation for the post-World War II period and could then not find any significant effects for the unionisation variables. The estimated equation takes the form:

$$
\begin{aligned}
\text { ARI }= & 1.00 \cdot \text { CORP }+0.90 \cdot \text { LIB } \\
& (0.11):(0.08) \\
& =0.25 \cdot \text { CORP } \cdot \text { UNION }+0.27 \cdot \text { LIB.UNION } \\
& (0.22) \quad(0.27)
\end{aligned}
$$

Barro also attempted to examine the effects of government regulations that reduce labour turnover, assuming that such regulations lead to greater persistence of unemployment. The empirical results were rather inconclusive, however, perhaps due to the fact that very crude proxies were used. Indeed, Barro's empirical analysis is based rather crude measures of the key variables. Time series variation in unionisation rates is ignored, and he does not hesitate to use the ratio of government expenditures to GNP as "proxy for government regulations that inhibit labour turnover". Less famous economists would almost certainly have been more reluctant to use such crude proxies. Barro does not go very far in his attempts to explain cross-country differences in unemployment persistence.

An unemployment equation estimated by Layard (1989) sheds more light on possible determinants of unemployment persistence. Layard makes use of pooled country data for the period 1962-88, and attempts to explain unemployment across 19 different countries. The estimated equation takes the form ( $t$-values are in parentheses):

$$
\begin{aligned}
& \log u_{t}=[0.91+0.0098 \cdot B D-0.012 \cdot \text { CORP }-0.0026 \cdot \text { LMP }] \log u_{t-1} \\
& (39.9) \cdot(1.6) \quad(4.3) \quad(2.2) \\
& \text { + other variables. }
\end{aligned}
$$

$B D$ is benefit duration, CORP is an index of centralisation in wage bargaining, and LMP is expenditure on active labour market policies per unemployed person relative to output per worker. The coefficient for lagged unemployment, which captures the degree of persistence, is thus allowed to vary depending on differences in labour market policies and wage bargaining institutions. Layard's results suggest that corporatism as well as active labour market policies helps to reduce unemployment persistence. Similar results are obtained by Jackman, Pissarides and Savouri (1990), who estimate Beveridge curves on a pooled country data set for the period 1971-88. They find that unemployment persistence is negatively related to expenditures on labour market policies.

The use of pooled country data sets for analyses of macroeconomic performance has its obvious pros. It provides more variance in the data, and should contribute to sharper estimates of key parameters related to policies and institutions. It is however difficult to account for many of the country-specific effects, and the specifications may therefore be seriously mis-specified. Barro's simplistic regressions illustrate how the costs of collecting relevant country-specific data may induce the researcher to pick variables that are easily accessed, although the variables would never have been contemplated in regressions for any single country. 


\section{b) Job security provisions}

The dynamics of unemployment may be crucially dependent on job security provisions, and Bertola (1990) documents evidence in favour of this hypothesis. He compares ten countries (Denmark, Belgium, France, Germany, Netherlands, Italy, Sweden, the United Kingdom, Japan and the United States) ranked in terms of job security; Italy comes at the top (most restrictions on firings), whereas the United States is considered to have the least restrictive practices.

Bertola estimates changes in unemployment on changes in GDP and finds that the responsiveness of unemployment to output changes is lower in high job-security countries. He also finds that unemployment persistence, measured by the sum of the first and the second-order autoregressive coefficients, is correlated with job security provisions; unemployment is in general more persistent in economies with the most restrictive job security provisions. There is, however, no obvious relationship between job security rankings and average unemployment, a result that is consistent with Bertola's theoretical model.

Lazear (1990) has examined the effects of job security provisions on unemployment, using a pooled data set made up of 22 countries and covering the period 1956 to 1984 . . He focuses on two variables, namely severance pay and advance notice. The former variable is measured as the number of months of salary given to workers as severance pay upon dismissal after ten years of service; advance notice is defined as the number of months' notice required before termination of workers with ten years of service. One might have expected that these variables should have been used to investigate persistence in unemployment, but Lazear ignores dynamics altogether and focuses on the level of unemployment. The specifications are very simplistic (or "parsimonious" to use Lazear's preferred characterisation). The unemployment rate is essentially explained by the two job security variables plus time trends common to all countries. The results are not very conclusive, but seems to suggest that mandated severance pay would reduce the employment-population ratio and possibly increase unemployment. It is remarkable that the diversity of unemployment experience among countries is attempted to be explained by such crude specifications. The estimates are almost certainly biased by omitted variables and omitted dynamics, and should not be taken very seriously.

Issues of persistence are not explored in Lazear's paper. Barro, however, used Lazear's measures of severance pay and advance notice in some of his attempts to account for cross-country differences in unemployment persistence (Barro 1988). The regression results are not shown but Barro reports ( $p$. 36) that "the severance and notice variables turned out not to have significant effects on the AR1 coefficients". It is surprising to find that job security provisions will increase the level of unemployment without having. any effect on unemployment persistence. Barro's negative results cast additional doubts on Lazear's exercises.

\section{Wages and unemployment}

Early empirical work on wage equations focused on the relationship between unemployment and nominal wage increases. Empirical studies from the past decade have typically relied on more or less explicitly formulated 
bargaining models. Such models yield real wage equations rather than conventional Phillips curves; the level of unemployment exerts downward pressure on real wages (except in extreme versions of insider-outsider models).

The evidence in favour of the hypothesis that unemployment exerts downward pressure on real wages is overwhelming. Table 2 shows estimates from three studies based on aggregate time series data. The unemployment-elasticity of real wages is in general rather small and varies across countries; there is some tendency for the elasticity to be higher (in absolute value) in countries with more centralised bargaining institutions (such as Sweden, Norway, Finland and Austria).

Studies based on more disaggregated data confirm the results from aggregate time series. A number of studies for different countries - - using panel data on firms, cross-section data on individual workers or disaggregated industry data - - find strong support for the hypothesis that unemployment matters for wage setting. The extreme version of the insider-outsider model does not seem to fit the facts.

\section{a) Non-linearities and long-term unemployment}

The original Phillips curve was typically taken to be non-linear, and recent work on real wage equations has examined whether the "wage curve" .. a function relating real wages to the level of unemployment - has a similar shape. The evidence from aggregate wage equations is mixed; some studies find that the $\log$ of the unemployment rate is the relevant variable, whereas other studies are unable to discriminate successfully between alternative functional forms.

Evidence from micro data is so far limited, but there is some support for non-linearities (Blanchflower and Oswald, 1990). Figures 1 and 2 display estimated wage curves for the United Kingdom and the United States based on cross-section data on individual workers (with regional unemployment rates imputed to each individual). The estimations control for a large number of observable job- and worker-characteristics. The estimated wage curves are convex to the origin, so that unemployment increases exert stronger wage-reducing pressure the lower is the unemployment rate. This is a potentially important result, since it suggests that shocks to labour demand may have large employment effects -- and negligible effects on the real wage -when there is high unemployment. Strong real wage rigidity may appear once the economy hits very high unemployment rates.

The interpretation of such evidence from cross-section wage equations is not entirely unambiguous, however. One popular strand in the literature on regional unemployment differences emphasises equalising differences; labour mobility tends to equalise expected wages (or utilities) across regions so that regions with high unemployment should simultaneously have high wages. Some U.S. studies have found at least some weak support for this hypothesis (Hall. 1972; Marston, 1985).

Models emphasising outsider ineffectiveness predict that long-term unemployment should have negligible effects on wage setting. Empirical results supporting this hypothesis are presented by Layard and Nickel1 (1986) and Nickell (1987) using time-series data for the aggregate U.K. economy, and by 
Table 2

The unemployment-elasticity of real wages in various countries

\begin{tabular}{llll}
\hline & BLN & AM & EUP \\
\cline { 2 - 2 } & -0.03 & & \\
Austria & -0.10 & -0.04 & -0.03 \\
Belgium & -0.02 & -0.02 & -0.004 \\
Canada & -0.01 & $\ldots$ & \\
Denmark & -0.01 & -0.01 & -0.01 \\
Finland & -0.02 & -0.04 & \\
France & -0.03 & -0.02 & \\
Germany & -0.03 & -0.02 & -0.004 \\
Ireland & -0.03 & -0.01 & \\
Italy & 0 & -0.01 & -0.01 \\
Japan & -0.41 & -0.15 & \\
Netherlands & -0.01 & -0.03 & \\
New Zealand & -0.01 & & \\
Norway & -0.06 & -0.07 & \\
Spain & -0.07 & -0.01 & \\
Sweden & -0.08 & -0.05 & \\
Switzerland & -0.23 & -0.05 & \\
United Kingdom & -0.01 & -0.01 & \\
United States & -0.003 & -0.01 & \\
\hline & & & \\
\hline
\end{tabular}

Notes: The three studies are Bean, Layard and Nickell (BLN, 1986); Alogoskoufis and Manning (AM, 1988); and European Unemployment Programme (EUP), summarised by Dreze and Bean (1990). 
Figure 1

U.K. Wage Curve

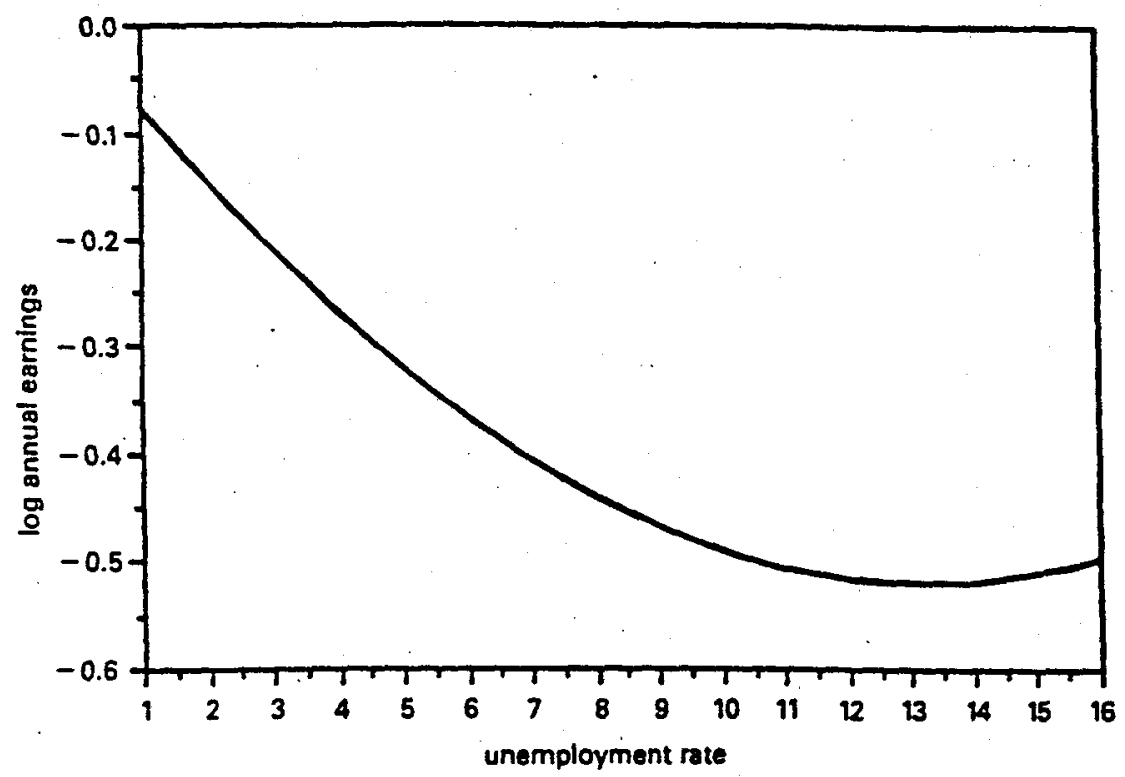

Source: Blanchflower and Oswald (1990).

Figure 2

U.S. Hage Curve

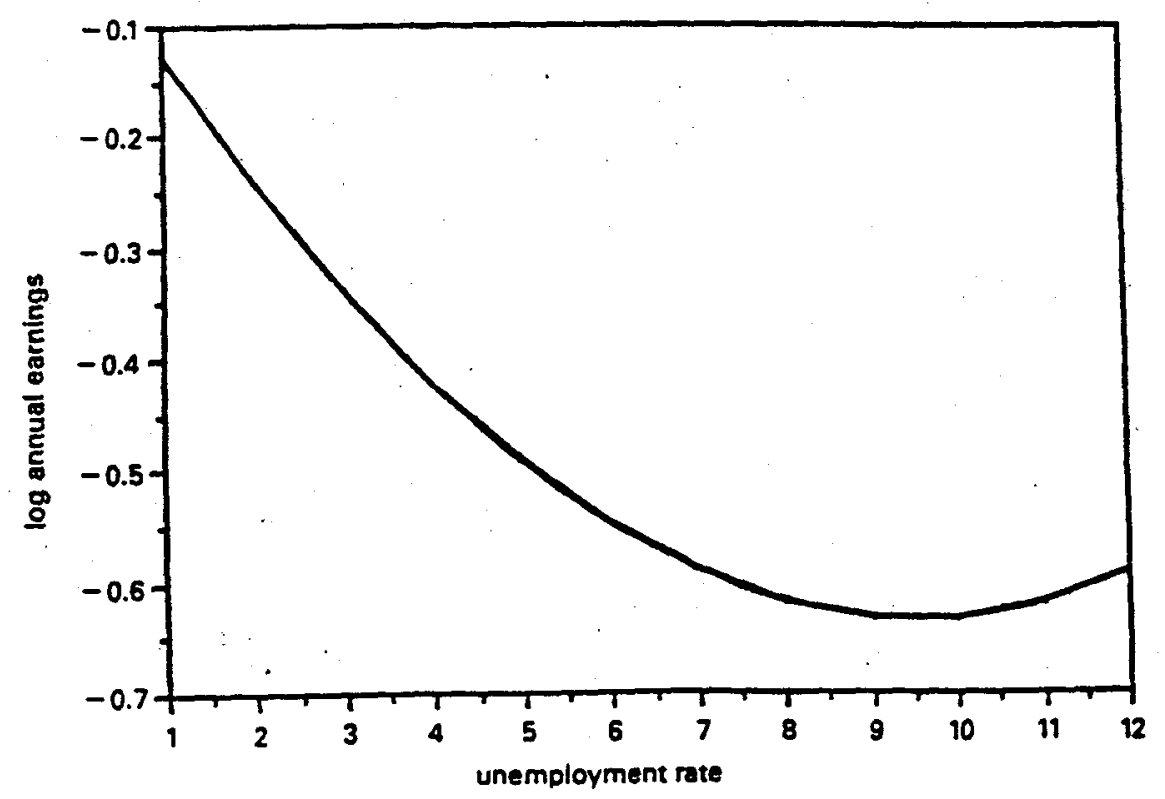

Source: Blanchflower and Oswald (1990). 
Nickell and Wadhwani (1990) using panel data on British firms. Similar results are obtained by 'Eriksson, Suvanto and Vartia (1990) on Finnish time-series data, whereas Holmlund (1990) finds little support for the hypothesis in Swedish time series; long-term unemployment is, however, relatively unimportant in Sweden compared to most other OECD countries. Favourable results are also reported by Coe (1988), who estimates wage change equations for six European countries (Germany, France, the United Kingdom, Austria, Finland and the Netherlands); the results indicate that long-term unemployment exerts weak downward pressure on wage increases.

These results are questioned by Blanchflower and Oswald (1990), who in their micro cross-section equations find that the duration composition of unemployment does not matter once non-linearities are controlled for. A recent paper by Blackaby, Bladen-Hovell and Symons (1990) finds support, however, for the Layard-Nickell hypothesis in British cross-section data; duration composition dominates non-linearities. The reasons for the different results are not clear. one possible explanation is that Blackaby. Bladen-Hovell and Symons have a specification that incorporates controls for regional price differences.

In some sense, the question of whether or not long-term unemployment belongs to the wage equation is a functional form issue. The discussion and results in Nickell (1987) are illuminating. The estimated real wage equation for Britain is of the form:

$$
w \cdot p=-0.104 \cdot \log u+0.212 \cdot \text { LTU + other variables, }
$$

where LTU (1ong-term unemployment) is the proportion of the unemployed with more than one year of unemployment. Unemployment thus exerts downward pressure on wages, but this effect becomes more diluted the higher is the fraction of long-term unemployment. Long-term unemployment is itself a function of unemployment, however, as is exemplified by Nickell's regression equation:

$$
\begin{aligned}
& \text { LTU }=0.05+0.6 \cdot \text { LTU }_{-1}=2.4 \cdot u+5.6 \cdot u_{-1}-2.2 \cdot u_{-2} \\
& \begin{array}{llll}
(3.7) & (5.6) & (6.5) & (2.4)
\end{array}
\end{aligned}
$$

$\overline{\mathrm{R}}=0.84$ (t-ratios in parentheses).

The equation gives a dynamic relationship between the share of the long-term unemployed and the unemployment rate. When unemployment increases there is initially a fall in the long-term share as entry into unemployment rises. In the long run, however, there is a positive relationship between the long-term unemployment and the level of unemployment (as is clear from the steady-state version of the estimated equation above).

The estimated LTU-equation can be substituted into the wage equation to yield a relationship between real wages and current and lagged unemployment:

$$
\begin{gathered}
w-p=-0.104 \cdot \log u+0.53 \cdot u-1.17 \cdot \Delta u-0.36 \cdot \Delta^{2} u \\
+ \text { other variables. }
\end{gathered}
$$

The positive coefficient on the unemployment rate arises because of the positive long-run relationship between the level of unemployment and the 
long-term proportion. The large negative difference term is due to the fact that an increase in unemployment initially reduces the long-term proportion. The combination of a negative $\log u$ term and a positive $u$ term means that, in the long run, increases in unemployment will only reduce wages up to certain point ( 19 per cent in this particular case): above that point further increases in unemployment will actually raise wages because of a dominant long-term proportion effect.

In conclusion, it must be stressed that the empirical work so far on non-linearities and duration effects in the wage equation have been rather inconclusive. It is not surprising that regressions on time series data for a single country may be insufficient to deliver clear results. But the varying results on cross-section data illustrates that micro data offer no panacea for empirical research in this field. Unemployment rates by region tend to be correlated with other regional or industrial variables, and small changes in specifications can influence results on functional forms or duration effects.

\section{b) Membership effects}

Several studies have tried to test the key insider-outsider hypothesis that wages are inversely related to the size of the incumbent work force.- The usual procedure here is to include the lagged employment level in the wage equation. The results are mixed but on the whole not very supportive to the insider-outsider hypothesis. Nickell and Wadhwani (1990) find some supportive evidence, but only for one of their samples. Nickell and Kong (1988) report similar inconclusive results, with supportive evidence for only some industries. Holmlund and Zetterberg (1989) reject the hypothesis in a study that exploits industry data for five different countries (Sweden, Norway. Finland, Germany and the United States). Studies of wage determination in Japan (Brunello and Wadhwani, 1988) and in Canada (Oswald and Christofides. 1989) also provide evidence against the hypothesis that the size of the incumbent work force is important for wage setting behaviour.

More favourable evidence is reported by Burda (1990). He makes use of data on union membership in aggregate manufacturing in Germany. When lagged membership is included in the wage equation, the estimated coefficient is negative and significant as the insider-outsider theory predicts.

A maintained hypothesis in all of this research is that the size of the insider pool is well captured by initial employment (or initial membership). Many countries have however experienced an increase in the number of temporary workers, i.e. workers hired for a fixed period of time. perhaps in part as a response to higher costs of hiring and firing employees. One would expect that this development changes the relationships between total employment and the insiders which are powerful in wage setting. Existing empirical work has however not paid much attention to issues regarding the appropriate measure of the insider pool, but have rather taken initial employment (or membership) as adequate proxies.

\section{c) Moving natural rates}

The fact that European unemployment has remained high without marked disinflation may reflect changes in the natural rate for various structural reasons, but the hysteresis hypothesis offers an alternative view. One sharp 
alternative is that the equilibrium unemployment rate adjusts with a lag to actual unemployment. Coe (1988) and to some extent Solow (1990) have estimated wage change equations to examine this alternative hypothesis.

Coe experimented with several alternative proxies for the natural rate, including lagged unemployment and a moving average of past unemployment rates. The degree of hysteresis is taken to be the speed at which the natural rate adjusts to actual unemployment. The extreme case is when the natural rate is equal to last period's unemployment. Suppose that the wage change equation takes the form:

$$
w-w_{-1}=B Z+\gamma\left(u-u^{*}\right)
$$

where $Z$ is a vector of variables which affect wage-setting behaviour and $u^{*}$ is the natural rate. This equation translates into a relationship between wage inflation and changes in unemployment in the extreme case where the natural rate is equal to actual unemployment in the previous period. Coe finds little evidence for hysteresis in the United States, Japan and Italy whereas strong evidence for hysteresis is found for the United Kingdom.

\section{Wages and firm performance}

When there is bargaining over wages there is also scope for rent sharing, in contrast to the standard competitive model which does not include a relationship between wages and firm performance, except for the short run. The idea of rent sharing fits nicely into the basic insider-outsider framework; indeed, the extreme version of this framework implies that only firm-specific factors matter for wage setting.

A number of econometric studies document that firm-specific factors are important for wage outcomes. Blanchflower, Oswald and Garrett (1990) use British cross'section establishment data which include managers' assessment of the establishments (relative) financial performance. They are able to include a large number of controls, including unionisation status and a measure of product market power as well as industry dummies. Financial performance is found to have a significant and positive effect on wages; establishments in the best-performance category pay between 7 and 14 per cent more than those in the lowest performance category.

Nickell and Wadhwani (1990) exploit British panel data on firms and control for unobserved labour quality differences that are constant over time. They find positive and significant insider effects. They estimate logarithmic wage equations of the form given by equation [8] above, i.e.

$$
\mathrm{w}=\alpha_{0}+\alpha_{1}\left(\mathrm{p}+\mathrm{q}-\delta_{1} \mathrm{n}-1\right)+\left(1-\alpha_{1}\right)\left(\overline{\mathrm{w}}-\delta_{2} \mathrm{u}+\delta_{3} \mathrm{~b}\right)
$$

remembering that $\mathrm{p}$ is $\log$ output price and $\mathrm{q}$ is $\log$ productivity. The wage is thus seen as a combination of insider variables (the first parenthesis) and outsider variables (the second parenthesis). The estimated insider weight ( $\hat{a}_{1}$ ) is found to be in the range between 0.08 and 0.13 . The insider effect may appear small but it is sufficiently big to produce substantial wage differentials over time as a result of differences in firms performance. 
Nickell and Wadhwani calculate that an "insider gap" of 18 per cent has been generated over a period of nine years.

Holmlund and Zetterberg (1989) study the determinants of industry wages in five countries with different wage bargaining institutions: Sweden. Norway. Finland, Germany and the United States. The main issue under investigation is whether industry wages respond to firms' performance in the sector, or whether they are largely determined by general economic conditions. Industry wages in the United States are shown to exhibit substantial responsiveness to changes in the sector's relative price and productivity performance, in the short run as well as in the long run; the estimated U.S. insider weight is around 0.4 . The magnitude of wage responses to sectoral conditions are modest in Germany (with estimated insider weights in the range between 0.1 and 0.15 ), whereas insider effects are largely negligible in the Nordic countries. Centralisation in the Nordic countries does not seem to be just an institutional facade. but appears to have significant behavioural consequences.

The results by Holmlund and Zetterberg are largely consistent with earlier results for the United States by Bell and Freeman (1985), and with results for Canada reported by Christofides and Oswald (1989). Rent sharing thus seems to be a distinctive aspect of wage determination in the United States, a result at variance with competitive labour market models. Unions 'do not seem to be necessary for rent sharing, although there is evidence that the magnitude of the insider effect depends on union power; the higher union density, the larger the wage response to sectoral price and productivity changes (Holmlund and Zetterberg, 1989).

\section{Duration dependence in unemployment}

Does the probability of re-employment fall as the elapsed duration of a spell of unemployment increases? This hypothesis is closely related to the outsider ineffectiveness hypotheses, and it has been examined in a rich microeconometric literature on unemployment duration. The term "positive duration dependence" refers to the case when the re-employment probability increases with elapsed duration; "negative duration dependence" is present when the re-employment probability falls over the spell of unemployment. This literature only rarely addresses the sources of duration dependence, but there are a few studies that explore how the unemployed individual's behaviour changes over the spell of unemployment.

The literature has emphasised the distinction between "true" and "spurious" duration dependence. The former case reflects time-varying processes related to the worker's search effort or reservation wage. skill deterioration, or duration effects in employers recruitment behaviour. In the standard search framework these processes affect either the unemployed worker's reservation wage or his probability of attracting job offers, the latter in part influenced by own search efforts.

Spurious duration dependence reflects unmeasured heterogeneity among the unemployed. Suppose that the unemployed differ with respect to an unobserved human capital characteristic that affects the probability of locating job offers. "High-quality" workers will be over-represented among the short-term unemployed whereas workers with less favourable characteristics will frequently be found among groups with long duration. Observing that exit rates from 
unemployment are higher among short-term unemployed than among long-term unemployed does not, per se, offer strong evidence of negative duration dependence; this pattern is exactly what one would expect when individuals differ in measured and unmeasured attributes.

Recent microeconometric research on unemployment duration include Ham and Rea (1987), who examine data from Canada; Jensen and Westergàrd-Nielsen (1990) and Jensen (1990) look at Danish data; Dell'Aringa and Lodovici (1988) use Italian data on displaced workers; Löfgren and Engström (1989), Edin (1989) and Bergstrom and Edin (1989) deal with duration dependence in Swedish unemployment; Narendranathan and Stewart (1990) investigate British data; Katz (1986), Katz and Meyer (1988), Han and Hausman (1990) and Meyer (1990) analyse unemployment duration in the United States.

Devine and Kiefer (1990a) offer a recent extensive review of the literature on unemployment duration. In a summary of their survey (Devine and Kiefer, 1990b) they conclude:

\begin{abstract}
"Results on duration dependence in the transition rate into employment are quite sensitive to specification. Findings of strong negative duration dependence in the hazard appear to result from uncontrolled heterogeneity. As expected, the estimates of the extent of duration dependence declines as heterogeneity is controlled. A number of studies find that duration dependence decline as heterogeneity is controlled. A number of studies find that duration dependence is insignificant after controlling for heterogeneity with a suitable list of explanatory variables (time-varying variables, in particular) or with a mixing distribution for unobserved heterogeneity. There is some evidence of positive duration dependence. As noted, reservation wage studies tend to find a slight decline in the reservation wage with duration, which is consistent with this finding for the hazard."
\end{abstract}

Sorting out true and spurious duration dependence involves difficult econometric problems. The presence of unobservables tends to bias the estimates towards negative duration dependence. The fact that so many studies find no, or even positive, duration dependence suggests that the hypothesis of outsider effectiveness should be regarded as a conjecture in need of further investigation. This conclusion is reinforced by evidence on search effort among long-term unemployed in Britain.

\title{
Long-term unemployment and search effort in Britain
}

Long-term unemployment has been pervasive in Britain during the 1980s. Those unemployed for over a year accounted for over 40 per cent of total unemployment in 1986, 1987 and 1988. The sharp fall in unemployment that occurred. in the late 1980 s was accompanied by a sharp fall in long-term unemployment. In fact, there is evidence that the long-term unemployed left the unemployment register at a faster rate than the short-term unemployed (Robinson, 1990a). Some of this effect is however likely to be the result of special labour market programmes, including policies that encourage job search among the long-term unemployed.

The substantial fall in British long-term unemployment is broadly consistent with direct evidence on job search behaviour among the unemployed. 
A research project on local labour markets in the late 1980 s offers interesting evidence on this issue (Robinson, 1990b). The project included interviews with unemployed individuals in different regions and with different length of spells of unemployment. The survey evidence suggested that most of the long-term unemployed had not given up search. The reduction in search effort over the spell of unemployment was marginal; job search activity appeared to drop off markedly only for those unemployed for more than five years.

Econometric evidence reported by Jones (1989) gives a similar picture. Time spent in various job search activities in Britain (in 1982) did not decline much with the length of unemployment; those unemployed for over two years spent on average 5.3 hours per week looking for jobs, whereas the mean weekly hours of search was slightly under six.

Hughes and McCormick (1990) estimated logit equations explaining the probability of searching via a direct employer-contact in Britain. This kind of search declined slowly over the spell of unemployment, with a marked drop after two years of unemployment.

Attempts to estimate how search effort changes over a spell of unemployment have so far not controlled for unobserved heterogeneity: data on repeated spells may be useful for this purpose. It seems likely that failure to control adequately for unobserved characteristics of job seekers tends to produce estimates of declining search effort over the spell. Unmeasured attributes that affect the individual's search effort may well be positively correlated with his ability to extract job offers; unobserved heterogeneity, rather than true duration dependence, may explain why long-term unemployed individuals are sometimes found to search less intensively than the short-term unemployed. Existing estimates of duration dependence in search effort are likely to overstate the drop off in search over the unemployment spell.

Negative duration dependence in unemployment may also reflect employer discrimination against the long-term unemployed. Anecdotal evidence gives some support for the discrimination hypothesis. Interviews with (a limited number of) British employers revealed that job applicants often were rejected simply because they were long-term unemployed (Robinson, 1990b).

\section{Conclusions}

Recent empirical work on unemployment persistence and insider-outsider forces in wage setting has discovered some new relationships, but also confirmed results from an older literature on wage determination. The following points summarise some of the major findings.

i) Unemployment exhibits substantial persistence. The degree of persistence is higher for the post-World War II period than for earlier periods, and higher in major European countries than in the United States. The reasons for cross-country differences in unemployment persistence are not well understood. but there is some evidence that persistence is increased by employment security provisions and reduced by centralised wage bargaining institutions and active labour market policies. 
ii) There is overwhelming evidence that higher unemployment reduces real wages. Extreme versions of insider-outsider models, which imply no negative relationship between unemployment and real wages, are refuted by a large number of studies using both micro and macro-data.

iii) There is some evidence that long-term unemployment exerts weak downward pressure on wages. The exact causal mechanisms at work are largely unknown, however. The notions that long-term unemployment reduces search effort, or results in human capital deterioration, are in general not confirmed by microeconometric studies of unemployment duration. Many studies find positive duration dependence once heterogeneity is controlled for appropriately.

iv) A key theoretical prediction from the insider-outsider literature is that wages are inversely related to the size of the firm's incumbent work force. This prediction has so far received rather little support in the empirical studies.

v) There is substantial evidence that firms performance matters for wage outcomes. Price and productivity improvements in a sector appear to translate into long-lasting wage premiums for workers in the sector. This relationship is strong in economies with decentralised bargaining structures, but negligible in economies with centralisation in wage bargaining.

Research in this field is far from unfinished business. There have been rather few empirical studies based on micro data, and several results do not seem to be particularly robust. The fact that we do not have a good understanding of the cross-country differences in unemployment and unemployment persistence, makes it difficult to suggest unambiguous policy-implications. There is little doubt, however. that the research on insider power and unemployment persistence has demonstrated how temporary contractionary policies may have long-lasting effects on unemployment. It has thereby also become clear that the costs of sharp deflationary policies may be much higher than one would expect according to earlier views on unemployment. There is some evidence that unemployment persistence can be reduced by labour market policies and by institutional reforms of the wage bargaining system towards more corporatist arrangements; this suggests that there may be better ways to reduce inflation than relying on deflationary policies alone.

\section{DIRECTIONS FOR FUTURE. RESEARCH}

Empirical research on unemployment and wage determination has been dominated by the use of macroeconomic time series. Researchers have only recently started to exploit more disaggregated data. such as data on industries or individual firms. We believe that more widespread use of micro data is necessary in order to cast sharper.light on a number of issues we have discussed in this paper. One should keep in mind, however, that results from partial equilibrium micro studies do not carry over without qualifications to general equilibrium implications. 
Another avenue whereby empirical work can be improved involves cross-country empirical work. This approach has so far only rarely been adopted, presumably because of the difficulties involved in putting together comparable data sets. However, cross-country comparisons seem crucial in order to explore the effects of different institutional arrangements and policies.

\section{Wage determination}

The wage-setting models that emphasise insider power are in general. concerned with wage formation at the firm level. Tests of key hypotheses should therefore preferably be undertaken on micro data Data bases on individual firms are rare, however, and very few studies have actually used firm-level data in empirical work on wage determination. Such data bases have to be developed within the different countries, and are unlikely to be available in the near future for cross-country empirical work.

Available industry-level data can. however, be exploited much more than has so far been the case. Data at the industry level on, for example. wages. employment, profits, productivity and output prices, can be put to systematic use in a cross-country context. (Cf. Holmlund and Zetterberg. 1989 and Coe, 1990.) The research so far indicates that insider forces are important. in sectoral wage equations, and it is important to investigate whether these results are robust when the models are applied to data for many different countries.

Available quite strong evidence of relative price effects in sectoral. wage equations do not completely rule out competitive explanations. however. It is conceivable that the estimated effects capture firms attempts to recruit more workers by posting higher wages when they face product demand improvements. Research so far has not seriously addressed this possibility.

2. Individual behaviour during unemployment

The hypothesis of outsider ineffectiveness emphasises that the unemployed worker's search intensity may fall over the spell of unemployment. Available limited evidence gives no overwhelming support for this hypothesis. however. Studies that examine duration dependence in unemployment have rarely included the very long-term unemployed (with unemployment spells exceeding a year). It is important to collect data that include very long unemployment spells in order to examine the robustness of earlier results on duration dependence.

Research on individual search effort is in its infancy. Available results indicate that time allocated to search matters for the re-employment probability. It is striking, however, that search intensity appears very difficult to explain by standard variables proxying individual characteristics and labour market conditions (Jones, 1989)

More detailed research on search behaviour is desirable. This resench may need new measurement techniques in order to obtain reliable measures of search effort; studies of individual time use have accumulated substantial knowledge of appropriate survey designs. This research should also try to address the difficult econometric issues concerning unobserved heterogeneity. 
Do the observed duration effects in search intensity reflect behavioural changes over the spell of unemployment?

3. Employers recruitment behaviour

There is some evidence that employers favour the short-term unemployed when they have many applications for a vacancy. The evidence is largely anecdotal. however, and much more empirical research is needed in order to determine whether employers really discriminate against the long-term unemployed. If they do. this raises intriguing theoretical questions of why they discriminate if the long-term unemployed are as employable as the short-term unemployed. 
REFERENCES

Akerlof, G. and J. Yellen (eds.) (1987), Efficiency Wage Models of the Labor Market, Cambridge University Press.

Alogoskofis, G.S. and A. Manning (1988). "On the persistence of unemployment". Economic Policy 7.

Barro, R. (1988), "The persistence of unemployment", American Economic Review 78. Papers and Proceedings, pp. 32-37.

Bean, C., R. Layard and S. Nickell (1986). "The rise in unemployment: A multi-country study". Economica (Supplement) 53, S1-S22.

Bell, L. and R. Freeman (1985), "Does a flexible industry wage structure increase employment? The U.S. experience", NBER Working Papers. No. 1604 .

Bergström, R. and P.A. Edin (1989), "Time aggregation and the distributional shape of unemployment duration", mimeo. Uppsala University.

Bertola, G. (1990), "Job security, employment and wages", European Economic Review 34, pp. $851-886$.

Blackaby, D.H., R.C. Bladen-Hovell and E.J. Symons (1990). "Unemployment duration and wage determination in the U.K. Evidence from the FES 1980-86". Department of Economics. University of Manchester. Discussion Papers. No. 68 .

Blanchard. 0. and L. Summers (1986). "Hysteresis and the European unemployment problem", in S. Fisher (ed.). NBER Macroeconomics Annual, MIT Press.

Blanchard, 0 . and P. Diamond (1990), "Ranking, unemployment duration, and wages", (mimeo) MIT.

Blanchflower, D. and A. Oswald (1990), "The wage curve", Scandinavian Journat of Economics, 92 , pp. 215-235.

Blanchflower, D., Oswald, A. and M. Garett (1990), "Insider power in wage determination", Economica 57, pp. 143-170.

Brune11o. G. and S. Wadhwani (1989), "The determinants of wage flexibility in Japan: Some lessons from a comparison with the U.K. using micro-data". Center for Labour Economics. London School of Economics. Working Papers. No. 1116.

Burda, M. (1990), "Some evidence on the membership hysteresis hypothesis in Europe", Empirical Economics 15. pp. 143-161.

Calmfors. L. and A. Forslund (1990), "Wage setting in Sweden". in L. Calmfors (ed.). Wage Formation and Macroeconomic Policy in the Nordic Countries. Oxford University Press. 
Christofides, L. and A. Oswald (1989), "Real wage determination in collective agreements". NBER Working Papers, No. 3188.

Clark. A. and A. Oswald (1989), "An empirical study of union preferences", Discussion Papers. No. 352, Centre for Labour Economics, London School of Economics.

Coe, D.T. (1988), "Hysteresis effects in aggregate wage equations", in R. Cross (ed.).

Coe. D.T. (1990). "Insider-outsider influences on industry wages", Empirical Economics 15. pp. 163-183.

Cross. R. (ed.) (1988), Unemployment. Hysteresis and the Natural Rate Hypothesis, Basil Blackwell.

De11'Aringa, C. and M. Samek Lodovici (1988), "Determinants of unemployment duration for displaced workers", Labour 2, pp. 91-111.

Devine, T. and N. Kiefer (1990a), Empirical Labor Economics: The Search Approach. Oxford University Press.

Devine, T. and N. Kiefer (1990b), "The empirical status of job search theory", paper presented at the World Meetings of the Econometric Society. Barcelona.

Dreze, J. and C. Bean (1990), "European Unemployment: Lessons from a multicountry econometric study", Scandinavian Journal of Economics 92. pp. $135-165$.

Dunlop. J. (1948), "Productivity and the wage structure, in income, employment and public policy". Essays in Honor of Alvin Hansen, Norton.

Edin, P.A. (1989), "Unemployment duration and competing risks: Evidence from Sweden". Scandinavian Journal of Economics 91, pp. 639-653.

Edin, P.A. and J. Zetterberg (1989), "Inter-industry wage differentials: Evidence from Sweden and a comparison with the United States", Working Papers, 1989:8, Department of Economics, Uppsala University.

Eriksson. T., A. Suvanto and P. Vartia (1990), "Wage setting in Finland", in L. Calmfors (ed.), Wage Formation and Macroeconomic Policy in the Nordic Countries. Oxford University Press.

Franz, W. (1990). "Hysteresis in economic relationships: An overview". Empirical Economics 15, pp. 109-125.

Ha11. R. (1972). "Turnover in the labor force". Brookings Papers on Economic Activity 3 .

Ham, J. and S.A. Rea (1987). "Unemployment insurance and male unemployment in Canada". Journal of Labor Economics 5, pp. 325-353. 
Han. A. and J. Hausman (1990), "Flexible parametric estimation of duration and competing risk models", Journal of Applied Econometrics 5, pp. 1-28.

Holmlund, B. (1989), "Wages and employment in unionized economies: Theory and evidence", in B. Holmlund, K.G. Löfgren and L. Engström, Trade Unions. Employment, and Unemployment Duration, Oxford University Press.

Holmlund, B. (1990), Svensk Lönebildning - Teori. Empiri, Politik (Wage Formation in Sweden -- Theory, Evidence, Policy), Stockholm.

Holmlund, B. and J. Zetterberg (1989), "Insider effects in wage determination: Evidence from five countries", Working Papers 1989:11. Department of Economics, Uppsala University. Forthcoming in European Economic Review.

Hughes, G. and B. McCormick (1990), "Measuring unemployment and cyclical participation in the British labour market". Scandinavian Journal of Economics 92, pp. 247-269.

Jones, S. (1989), "Job search methods, intensity and effects", Oxford Bulletin of Economics and Statistics 51, pp. 277-296.

Jackman. R., C. Pissarides and S. Savouri (1990), "Labour market policies and unemployment in the OECD", Economic Policy, October.

Jensen, P. and N. Westergàrd-Nielsen (1990), "Temporary layoffs", in J. Hartog. G. Ridder and J. Theeuwes (eds.), Panel Data and Labor Market Studies. North-Holland.

Jensen, P. (1990), "Different escape routes from unemployment: Evidence and sensitivity analysis", paper presented at the meetings of the European Association of Labour Economists, Lund.

Katz, L. (1986), "Layoffs, recall and the duration of unemployment". NBER Working Papers. No. 1825.

Katz, L. and B. Meyer (1988), "Unemployment insurance, recall expectations and unemployment outcomes", NBER Working Papers, No. 2594.

Katz, L. and L. Summers (1989), "Industry rents: Evidence and implications". Brookings Papers on Economic Activity - Microeconomics, pp. 209-274.

Krueger, A. and L. Summers (1988), "Efficiency wages and the inter-industry wage structure", Econometrica 56, pp. 259-293.

Layard, R. (1989), European unemployment: Cause and cure", Centre for Labour Economics. London School of Economics Discussion Papers. No. 368.

Layard, R. and S. Nicke11 (1986), "Unemployment in Britain". Economica 53 , Supplement.

Layard, R. and C. Bean (1989). "Why does unemployment persist?". Scandinavian Journal of Economics 91. pp. 371-396. 
Lazear. E. (1990). "Job security provisions and employment", Quarterly Journal of Economics, CV, pp. 599-726.

Lindbeck. A. and D. Snower (1988), The Insider-Outsider Theory of Employment and Unemployment. MIT Press.

Löfgren. K.G. and L. Engström (1989), "The duration of unemployment: Theory and empirical evidence" in B. Holmlund. K.G. Löfgren and L. Engström, Trade Unions. Employment and Unemployment Duration, Oxford University Press.

Marston. S. (1985). "Two views of the geographic distribution of unemployment", Quarterly Journal of Economics, C, pp. 57-79.

Meyer. B. (1990). "Unemployment insurance and unemployment spells", Econometrica 58 . pp. $757-782$.

Mortensen, D. (1989), "The persistence of indeterminacy of unemployment in search equilibrium". Scandinavian Journal of Economics, 91, pp. 347-370.

Narendranathan, S. and M. Steward (1990), "An examination of the robustness of models of the probability of finding a job for the unemployed" in J. Hartog. G. Ridder and J. Theeuwes (eds.), Panel Data and Labor Market Studies. North-Holland.

Nickell, S. (1987), "Why is wage inflation in Britain so high?", Oxford Bulletin of Economics and Statistics, 49, pp. 103-128.

Nickel1. S. and P. Kong (1988), "An investigation into the power of insiders in wage determination", mimeo, Institute of Economics and Statistics. Oxford University.

Nickel1. S. and S. Wadhwani (1990), "Insider forces and wage determination", Economic Journal. 100, pp. 496-509.

OECD (1986). Flexibility in the Labour Market: The Current Debate, Paris.

Oswald. A. (1985), "The economic theory of trade unions: An introductory survey", Scandinavian Journal of Economics, 87, pp. 160-193.

Eencave1. J. (1985). "Wages and employment under trade unionism: Microeconomic models and macroeconomic applications", Scandinavian Journal of Economics. 87. pp. 197-225.

Phillips, A.W. (1958), "The relation between unemployment and the rate of change of money wage rates in the United Kingdom", Economica, 25. pp. $283-299$.

Pissarides. C. (1990). Equilibrium Unemployment Theory, Basil Blackwell.

Robinson. P. (1990a), "The consequences of the accidental boom. 1986-87": Campaign for Work Research Report (June). 
Robinson, P. (1990b), "Unemployment and local labor markets", unpuhlished manuscript.

Slichter, S. (1950), "Notes on the structure of wages", Review of Economics and Statistics, 32, pp. 80-91.

Solow, R. (1990), The Labor Market as a Social Institution. Basil Blackwell. 


\section{ECONOMIC AND STATISTICS DEPARTMENT WORKING PAPERS}

In April 1983, the Economics and Statistics Department initiated a new series of economic studies entitled ESD Working Papers.

The following titles have been circulated:

1. Use of Demand Elasticities in Estimating Energy Demand (out of print) Utilisation des élasticités de la demande dans l'estimation de la demande de l'énergie Axel Mittelstädt

2. Capital, Energy and Labour Substitution: The Supply Block in OECD Medium-Term Models Substitution du capital, de 1'énergie et du travail : le bloc de 1'offre dans les modèles à moyen terme de 1'OCDE (épuisé)

Patrick Artus

3. Wage Formation in France: Sectoral Aspects (out of print) Formation des salaires en France : aspects sectoriels (épuisé) Patrick Artus

4. Service Lives of Fixed Assets (out of print) Durée de vie utile des actifs fixes (épuisé)

Derek Blades

5. Resource Prices and Macroeconomic Policies: Lessons from Two Oil Price Shocks

Prix des ressources naturelles et politique macro-économique : les enseignements de deux chocs pétroliers (épuisé)

John Llewellyn

6. Output Responsiveness and Inflation: An Aggregate Study Souplesse de la production et inflation : étude globale David T. Coe and Gerald Holtham

7. The Determinants of Exchange Rate Movements (out of print) Les déterminants des mouvements des taux de change (épuisé) Graham Hacche

8. Simulated Macroeconomic Effects of a Large Fall in Oil Prices (out of print)

Simulation des effets macro-économiques d'une forte baisse des prix pétroliers

Flemming Larsen and John Llewellyn

9. Medium-Term Financial Strategy: The Co-ordination of Fiscal Monetary Policy (out of print)

Stratégie financière à moyen terme : 1a coordination des politiques monétaire et budgétaire (épuisé)

Jean-Claude Chouraqui and Robert Price

10. Price Dynamics and Industrial Structure: A Theoretical and Econometric Analysis (out of print)

Dynamique des prix et structure industrielle : une analyse théorique économétrique (épuisé)

David Encaoua (with collaboration from Paul Geroski and Riel Miller) 
11. Evidence on Income Distribution by Governments (out of print) L'Action exercée par l'Etat sur la redistribution du revenu Peter Saunders

12. Labour Force Participation: An Analysis with Projections Taux d'activité : analyse et projections James H. Chan-Lee

13. The Demand for Money and Velocity in Major OECD Countries (out of print) La demande de monnaie et la vitesse de circulation dans les grands pays de 1'OCDE

A. Blundell-Wignall, M. Rondoni and H. Ziegelschmidt

14. The Conduct of Monetary Policy in the Current Recovery La conduite de la politique monétaire dans la phase actuelle de reprise économique

Paul Atkinson and Jean-Claude Chouraqui

15. Structural Budget Deficits and Fiscal Stance (out of print)

Déficits budgétaires structurels et orientation de la politique

budgétaire (épuisé)

Patrice Muller and Robert W.R. Price

16. Monetary Policy in the OECD INTERLINK Model

La politique monétaire dans le modèle INTERLINK

A. Blundel1-Wigna11, M. Rondoni, H. Ziegelschmidt and J. Morgan

17. Real Gross Product in OECD Countries and Associated Purchasing Power Parities (out of print)

Produit brut réel et parités de pouvoir d'achat dans les pays de 1'OCDE (épuisé)

Peter Hill

18. The OECD Compatible Trade and Production Data Base (out of print) Base de données compatibles sur le commerce et la production de l'OCDE Derek Blades and Wendy Simpson

19. Nominal Wage Determination in Ten OECD Economies Détermination des salaires nominaux dans dix économies de 1'OCDE David T. Coe and Francesco Gagliardi

20. Profits and Rates of Return in OECD Countries Profits et taux de rendement dans les pays Membres de 1'OCDE James H. Chan-Lee and Helen Sutch

21. Real Interest Rates and the Prospects for Durable Growth Taux d'intérêt réels et perspectives de croissance durable Paul Atkinson and Jean-Claude Chouraqui

22. Energy Prices: Trends and Prospects

Les prix de l'energie : évolution et perspectives Axel Mittelstädt

23. Changes in the Composition of Output and Employment Changements dans la composition de la production et de l'emploi Axel Mittelstädt and Françoise Correia

24. Labour Market Flexibility and External Price Shocks Flexibilité du marché du travail et chocs extérieurs sur les prix F. Klau and A. Mittelstädt 
25. Discrepancies Between Imports and Exports in OECD Foreign Trade Statistics (out of print)

Escart entre les importations et les exportations dans les statistiques du commerce extérieur de 1'OCDE

Derek Blades and Marina Ivanov

26. Aggregate Supply in INTERLINK: Model Specification and Empirical Results

John Helliwel1, Peter Sturm, Peter Jarrett and Gérard Salou

27. Commodity Prices in INTERLINK

Gerry Holtham, Tapio Saavalainen, Paul Saunders and Helen Sutch

28. Exchange Rates and Real Long-Term Interest Rate Differentials: Evidence

for Eighteen OECD Countries

David T. Coe and Stephen S. Golub

29. Method of Calculating Effective Exchange Rates and Indicators of Competitiveness (out of print)

Martine Durand

30. Public debt in a medium-term context and its implications for fiscal policy (May 1986)

Jean-Claude Chouraqui, Brian Jones and Robert Bruce Montador

31. The OECD compatible trade and production data base 1970-1983

(March 1986)

Anders Brodin and Derek Blades

32. The formulation of monetary policy: a reassessment in the light of recent experience (March 1986)

Paul Atkinson and Jean-Claude Chouraqui

33. Mécanismes de transmission et effets macro-économiques de la politique monétaire en France: les principaux enseignements econométriques (March 1986)

Marc-Olivier Strauss-Kahn

34. Pure profit rates and Tobin's q in nine OECD countries (April 1986) James H. Chan-Lee

35. Wealth and inflation effects in the aggregate consumption function (July 1986)

G.H. Holtham and H. Kato

36. The government household transfer data base 1960-1984 (September 1986) Rita Varley

37. Internationalisation of financial markets: some implications for macroeconomic policy and for the allocation of capital (November 1986) Mitsuhiro Fukao and Masaharu Hanazaki

38. Tracking the U.S. external deficit, 1980-1985: experience with the OECD INTERLINK mode1 (February 1987)

Pete Richardson

39. Monetary policy in the second half of the 1980s: how much room for manoeuvre? (February 1987)

Kevin Clinton and Jean-Claude Chouraqui 
40. Tax reform in OECD countries: economic rationale and consequences (August 1987)

Robert P. Hagemann, Brian R. Jones and Robert Bruce Montador

41. A revised supply block for the major seven countries in INTERLINK (April 1987)

Peter Jarrett and Raymond Torres

42. OECD economic activity and non-oil commodity prices: reduced-form equations for INTERLINK (June 1987)

Gerald Holtham and Martine Durand

43. Import and export price equations for manufactures (June 1987)

Richard Herd

44. Price determination in the major seven country models in INTERLINK

(July 1987)

Ulrich Stiehler

45. International investment-income determination in INTERLINK: models for twenty-three OECD countries and six non-OECD regions (June 1987)

David T. Coe, Richard Herd and Marie-Christine Bonnefous

46. Recent developments in OECD's international macroeconomic model

(June 1987)

Pete Richardson

47. A review of the simulation properties of OECD's INTERLINK Mode1

(July 1987)

Pete Richardson

48. The medium-term macroeconomic strategy revisited (December 1987)

Jean-Claude Chouraqui, Kevin Clinton and Robert Bruce Montador

49. Are commodity prices leading indicators of OECD prices? (February 1988) Martine Durand and Sveinbjörn Blöndal

50. Private consumption, inflation and the "debt neutrality hypothesis": the case of eight OECD countries (January 1988)

Giuseppe Nicoletti

51. The effects of monetary policy on the real sector: an overview of empirical evidence for selected OECD economies (April 1988)

Jean-Claude Chouraqui, Michael Driscoll and Marc-Olivier Strauss-Kahn

52. The so-called "non-economic" objectives of agricultural policy

(April 1988)

L. Alan Winters

53. Alternative solution methods in applied general equilibrium analysis (April 1988)

Richard G. Harris

54. Tests of total factor productivity measurement (June 1988)

A. Steven Englander

55. Quantifying the economy-wide effects of agricultural policies: a general equilibrium approach (July 1988)

Jean-Marc Burniaux, François Delorme, Ian Lienert, John P. Martin and Peter Hoeller 
56. On aggregation methods of purchasing power parities (November 1988)

$J, R$. and $M$. Cuthbert

57. An international sectoral data base for thirteen OECD countries (November 1988)

F.J.M. Meyer-zu-Schlochtern

58. Empirical research on trade liberalisation with imperfect competition: a survey (November 1988)

J. David Richardson

59. Eliminating the U.S. federal budget deficit by 1993: the interaction of monetary and fiscal policy (December 1988)

Richard Herd and Byron Ballis

60. Compatible trade and production data base: 1970-1985 (November 1988) Claude Berthet-Bondet, Derek Blades and Annie Pin

61. Ageing populations: implications for public finances (January 1989) Robert P. Hagemann and Giuseppe Nicoletti

62. The economic dynamics of an ageing population: the case of four OECD economies (January 1989)

Alan J. Auerbach, Laurence J. Kotlikoff, Robert P. Hagemann and Giuseppe Nicoletti

63. Modelling housing investment for seven major OECD countries (December 1988)

Thomas Egebo and Ian Lienert

64. Revised groupings for non-OECD countries in OECD's macroeconomic model INTERLINK (January 1989)

Paul O'Brien, Laure Meuro and Arthur Camilleri

65. A post mortem on OECD short-term projections from 1982 to 1987

(February 1989)

Byron Ballis

66. Potential output in the seven major OECD countries (May 1989)

Raymond Torres and John P. Martin

67. Saving trends and behaviour in OECD countries (June 1989)

Andrew Dean, Martine Durand, John Fallon and Peter Hoeller

68. The impact of increased government saving on the economy (June 1989)

Richard Herd

69. The information content of the terms structure of interest rates: theory and practice (September 1989)

Frank Browne and Paolo Manasse

70. On the sequencing of structural reforms (September 1989)

Sebastian Edwards

71. Modelling business sector supply for the smaller OECD countries (October 1989)

Raymond Torres, Peter Jarrett and Wim Suyker

1990

72. The role of indicators in structural surveillance (January 1990) 
73. The saving behaviour of Japanese households (January 1990)

Kenichi Kawasaki

74. Industrial subsidies in the OECD economies (January 1990)

Robert Ford and Wim Suyker

75. Measuring industrial subsidies: some conceptual issue (February 1990) Neil Bruce

76. The dollar position of the non-U.S. private sector, portfolio effects, and the exchange rate of the dollar (February 1990)

Bixio Barenco

77. Monetary policy in the wake of financial liberalisation (April 1990)

Adrian Blundell-Wigna11, Frank Browne and Paolo Manasse

78. Indicators of fiscal policy: a re-examination (April 1990)

Jean-Claude Chouraqui, Robert P. Hagemann and Nicola Sartor

79. Suggestions for a new set of fiscal indicators (April 1990) Olivier Blanchard (MIT and NBER)

80. Fiscal indicators (April 1990)

Edward E. Gramlich, The University of Michigan

81. Financial liberalisation and consumption smoothing (forthcoming)

Adrian Blundell-Wignall, Frank Browne and Stefano Cavaglia

82. Economies and the environment: a survey of issues and policy options (July 1990)

Jon Nicolaisen and Peter Hoeller

83. Exchange rate policy in advanced commodity-exporting countries: the case of Australia and New Zealand (July 1990)

Adrian Blundell-Wignall and Robert G. Gregory

84. WALRAS - A multi-sector, multi-country applied general equilibrium model for quantifying the economy-wide effects of agricultural policies: a technical manual (August 1990)

Jean-Marc Burniaux, François Delorme, Ian Lienert and John P. Martin

85. Simulating the OECD INTERLINK Model under Alternative Monetary Policy Rules (October 1990)

Pete Richardson

86. Modelling wages and prices for the smaller OECD countries (October 1990) Kenichi Kawasaki, Peter Hoeller, Pierre Poret

87. The "PUZZLE" of wage moderation in the 1980s (November 1990)

Pierre Poret

88. Business investment in the OECD economies: recent performance and some implications for policy (November 1990)

Robert Ford, Pierre Poret

89. A Survey of Studies of the Costs of Reducing

Greenhouse Gas Emissions (December 1990)

Peter Hoeller, Andrew Dean and Jon Nicolaison 
90. The Public Sector: Issues for the 1990s(December, 1990)

Howard Oxley, Maria Maher, John P. Martin, Giuseppe Nicoletti and Patricia Alonso-Gamo

\section{1}

91. Infrastructure and Private-Sector Productivity (January 1991) Robert Ford and Pierre Poret 